\title{
RESEARCHES REGARDING THE INFLUENCE OF THE NUTRITION SPACE AT DRACOCEPHALUM MOLDAVICA L. (DRAGONHEAD) SPECIES CULTIVATED UNDER THE CONDITIONS OF A.R.D.S. SECUIENI
}

\author{
MARGARETA NAIE ${ }^{1 *}$, OANA MIRZAN ${ }^{1}$, DOBREA DANIELA-IULIANA ${ }^{1}$ \\ ${ }^{1}$ Agricultural Research and Development Station Secuieni, Neamt County, 617415, \\ Romania
}

\begin{abstract}
The present paper presents the results on the influence of the nutrition space at Dracocephalum moldavica L., cultivated under the conditions of A.R.D.S. Secuieni between 2016 and 2017. Following the interaction of the factors, the distance between the rows and the distance between the plants per row was found that in the variant sown at 70 $\mathrm{cm}$ between the rows and $15 \mathrm{~cm}$ between the plants per row there was an increase in the average number of branches $(2,27)$. The variants sown at $50 \mathrm{~cm}$ and $70 \mathrm{~cm}$ between the rows achieved deficit production, very significant compared to the control sowing at the 25 $\mathrm{cm}$ between the rows.
\end{abstract}

Keywords: melliferous plant, nutrition space, dragonhead

\section{INTRODUCTION}

Dragonhead (Dracocephalum moldavica L.) is an annual aromatic plant belonging to family of Lamiaceae [1]. The origin of this plant is reported from southern Siberia and the Himalaya and naturally grows in temperate Zones of Europe and Asia [2, 3].

It is used to relieve headaches, abdominal pain, nervous system disorders, kidney pain, gastrointestinal pain and teeth [4]. Environmental factors have a major impact on the yield and active principles of medicinal and aromatic species. However, it is not possible to control these factors, but the potential productive of this species can be improved by improving technology cultivation $[5,6]$.

The researches were carried between 2016 and 2017 at A.R.D.S. Secuieni and aimed establish the optimal nutritional space for the species Dracocephalum moldavica L. in order to develop the technology cultivation.

\section{MATERIAL AND METHOD}

The researches were carried between 2016 and 2017 at A.R.D.S. Secuieni on a typical cambic soil type . Characterized as being well supplied with mobile phosphorus (39 ppm - $\left.\mathrm{P}_{2} \mathrm{O}_{5}\right)$, moderately supplied in nitrogen with the soil nitrogen index of 2.1 , well supplied in mobile potassium $\left(161 \mathrm{ppm}-\mathrm{K}_{2} \mathrm{O}\right)$, slightly acidic, with the $\mathrm{pH}$ (in aqueous suspension) of 6.29 and a humus content of $2.3 \%$. At Dracocephalum moldavica (L.) species, the aim was to establish a technological link through the establishment of the optimal nutritional space in a bifactorial experience according to the subdivided parcel method in three repetitions.

\footnotetext{
* Corresponding author, email: marieta.naie@ scda.ro

(C) 2017 Alma Mater Publishing House
} 
Experienced factors are: A - the distance between rows with graduations: $25 \mathrm{~cm}, 50 \mathrm{~cm}$ and $70 \mathrm{~cm}$ and $\mathrm{B}-$ the distance between plants per row with graduations: continuous row, $15 \mathrm{~cm}$ and $25 \mathrm{~cm}$.

The soil work and the preparation of the germination bed consisted in releasing the soil from the plant debris in the pre-planting, stubble-turning and plowing at a depth of $30 \mathrm{~cm}$. In spring, preparation of the germination bed was made with a harrow disc and the sowing was done manually at a depth of $2 \mathrm{~cm}$. During the vegetation period at species Dracocephalum moldavica L., the observations and determinations were made which consisted in determining the average plant height, the average number of branches / plants, the average weight of the stem, the average weight of the leaves, the average weight of the flowers, the average weight of the plant. For the production of fresh herbs the plants were harvested manually until full blossom by cutting plants at a height of 5 $\mathrm{cm}$ from the ground. Seed harvesting was done by cutting plants with mowing, followed by barking. The seed obtained was conditioned by the small seed selector.

For the entire growing season of the dragonhead, the deviation from the multiannual average of temperatures varied between $0.7^{\circ} \mathrm{C}$ (2017) and $3.3^{\circ} \mathrm{C}$ (2016). From the temperatures point of view, the vegetation period of Dracocephalum moldavica L. in the experimental year compared to the multiannual average was characterized as very warm in 2016 and normal in 2017 (Table 1).

Table 1. Temperatures recorded at A.R.D.S. Secuieni meteorological station.

\begin{tabular}{|c|c|c|c|c|c|c|c|c|c|c|c|c|}
\hline \multirow{2}{*}{$\begin{array}{c}\text { Average } \\
\text { tempera- } \\
\text { ture } \\
{ }^{\circ} \mathbf{C} \\
\end{array}$} & \multicolumn{9}{|c|}{ Months } & \multirow{2}{*}{$\begin{array}{c}\text { Average } \\
\text { vegetation } \\
\text { period }\end{array}$} & \multirow[b]{2}{*}{ Deviation } & \multirow{2}{*}{$\begin{array}{c}\text { Vegetation } \\
\text { period } \\
\text { charact. }\end{array}$} \\
\hline & Jan & Febr & Mar & Apr & May & Jun & Jul & Aug & Sept & & & \\
\hline 2016 & -3.0 & 4.2 & 5.7 & 13.5 & 14.9 & 20.3 & 31.7 & 20.6 & 17.3 & 19.7 & 3.3 & Very warm \\
\hline 2017 & -5.7 & -1.8 & 7.0 & 9.1 & 15.4 & 20.3 & 20.4 & 21.2 & 16.3 & 17.1 & 0.7 & norm. \\
\hline $\begin{array}{c}\text { Multiann } \\
\text { ual } \\
\text { average }\end{array}$ & -3.8 & -2.3 & 2.6 & 9.4 & 15.4 & 18.8 & 20.3 & 19.5 & 14.8 & 16.4 & - & - \\
\hline
\end{tabular}

In terms of rainfall, the deviation from the multiannual rainfall ranged between 5.5\% (2016) and - 18.9\% (2017), 2016 being a normal one and 2017 less drastic (Table 2).

Table 2. Rainfall recorded at A.R.D.S. Secuieni meteorological station.

\begin{tabular}{|c|c|c|c|c|c|c|c|c|c|c|c|c|}
\hline \multirow{2}{*}{$\begin{array}{c}\text { Rainfall } \\
(\mathrm{mm})\end{array}$} & Jan & Febr & Mar & Apr & May & Jun & Jul & Aug & $\begin{array}{c}\text { Sep } \\
\mathrm{t}\end{array}$ & $\begin{array}{c}\text { Sum for } \\
\text { the } \\
\text { vegetatio } \\
\text { n period }\end{array}$ & $\begin{array}{c}\text { Deviatio } \\
\mathrm{n}\end{array}$ & $\begin{array}{c}\text { Vegetatio } \\
\mathrm{n} \text { period } \\
\text { charact. }\end{array}$ \\
\hline 2016 & 12.0 & 14.2 & 29.4 & 42.0 & $\begin{array}{c}120 . \\
2\end{array}$ & 161.0 & 4.0 & 32.0 & $\begin{array}{c}48 . \\
6\end{array}$ & 407.8 & 5.5 & norm \\
\hline 2017 & 7.3 & 17.0 & 101.6 & 54.4 & 59.4 & 49.4 & 72.2 & 23.0 & $\begin{array}{c}55 \\
2\end{array}$ & 313.6 & -18.9 & less dry \\
\hline $\begin{array}{c}\text { Multiann } \\
\text { ual } \\
\text { average }\end{array}$ & 20.5 & 19.6 & 25.4 & 46.8 & 64.8 & 84.3 & 84.0 & 61.4 & $\begin{array}{c}45 . \\
4\end{array}$ & 386.7 & - & - \\
\hline
\end{tabular}

\section{RESULTS AND DISCUSSION}

The average height of the plant was between $79.19 \mathrm{~cm}$ and $85.99 \mathrm{~cm}$. The variant sown at the distance of $25 \mathrm{~cm}$ between the rows and $15 \mathrm{~cm}$ between the plants per row (a1xb2), the difference from the control variant was negative, very significant $(4.64 \mathrm{~cm})$. A negative distinct difference was recorded at variant sown at $50 \mathrm{~cm}$ between rows and in continuous row $(2.44 \mathrm{~cm}$ ) compared to a1xb1 control (at $25 \mathrm{~cm}$ between consecutive row rows). Positive, distinctly significant differences were obtained at seed sowing at $25 \mathrm{~cm}$ between rows and $25 \mathrm{~cm}$ between plants per row $(3.48 \mathrm{~cm})$ (Table 3$)$.

Due to the interaction of the factors, the distance between the rows and the distance between plants per row was found that in the variant sown at $70 \mathrm{~cm}$ between the rows and $15 \mathrm{~cm}$ between the plants per row there was an increase in the average number of branches, the difference from the control (14.93 ) being positive, distinctly significant (2.27) are presented in Table 4. 
Regarding the average weight of the stem, the highest value was recorded at the interaction of a2xb3 (136.53 g) and the lowest at the interaction of a1xb2 (36.26 g). In Dracocephalum moldavica L. the average weight of the stem recorded positive, distinctly significant differences compared to the control at a1xb1 $(43.79 \mathrm{~g})$ at the interactions between a1xb3 (56.85 g - sown at $25 \mathrm{~cm}$ between rows and $25 \mathrm{~cm}$ between plants per row) and a $2 x b 3$ (66.96g - sown at $50 \mathrm{~cm}$ between rows and $25 \mathrm{~cm}$ between plants per row). Positive, very significant positive differences from the control were obtained in the a $3 x b 2$ interactions $(80.84 \mathrm{~g}-$ sown at $70 \mathrm{~cm}$ between the rows and $15 \mathrm{~cm}$ between the plants per row) and a3xb3 $(92.74 \mathrm{~g}-$ sown at $70 \mathrm{~cm}$ between the rows and 25 $\mathrm{cm}$ between plants per row) (Table 5).

The results obtained on the interaction of the studied factors showed that the average leaf weight of the species Dracocephalum moldavica L. recorded positive, very significant differences, at the interactions a3xb2 (106.65 g - sown at $70 \mathrm{~cm}$ between the rows and $15 \mathrm{~cm}$ between the plants per row) and a3xb3 (118.88 $\mathrm{g}-\mathrm{sown}$ at $70 \mathrm{~cm}$ between the rows and $25 \mathrm{~cm}$ between the plants per row) compared to the control variant $(54.17 \mathrm{~g})$ (Table 6).

Interactions between a1xb3 $(7.25 \mathrm{~g}$ - sown at $25 \mathrm{~cm}$ between the rows and $25 \mathrm{~cm}$ between the plants per row) and a $2 x b 3(10.56 \mathrm{~g}-$ sown at $50 \mathrm{~cm}$ between the rows and $25 \mathrm{~cm}$ between plants per line) influenced the mean weight of flowers compared to the a1xb1 $(7.06 \mathrm{~g})$, the difference being positive, distinctly significant. Positive, very significant differences were recorded in the a $3 \times \mathrm{xb} 2$ interactions $(11.73 \mathrm{~g}-$ sown at $70 \mathrm{~cm}$ between rows and $15 \mathrm{~cm}$ between plants per row) and a3xb3 $(21.63 \mathrm{~g}$ - sown at $70 \mathrm{~cm}$ between rows and $25 \mathrm{~cm}$ between plants per row) compared to control a1xb1 (7.06 g) (Table 7).

The average plant weight in Dracocephalum moldavica L. was evidenced by distinct positive differences compared to a1xb1 interactions $(104.40 \mathrm{~g})$ between a1xb3 (145.31 g at $25 \mathrm{~cm}$ between rows and $25 \mathrm{~cm}$ of plants per row) and a2xb3 (181.92 g - 50 cm between rows and $25 \mathrm{~cm}$ between plants per line). Very significant positive differences were observed in the a $3 x b 2$ interactions $(199.85 \mathrm{~g}-70 \mathrm{~cm}$ between the rows and $15 \mathrm{~cm}$ between the plants per row) and a3xb3 $(233.88 \mathrm{~g}-$ at $70 \mathrm{~cm}$ between the rows and $25 \mathrm{~cm}$ between the plants in a row) (Table 8).

Analyzing the interaction of the studied factors on the average production of fresh herb it was found that in variants sown at distances of $50 \mathrm{~cm}$ and $70 \mathrm{~cm}$ between rows the production were negative, very significant differences compared to the control sowing at $25 \mathrm{~cm}$ between the rows and in continuous row (Table 9).

The average seed yields were fluctuating and varied according to the distance between the rows and the plants per row. Variants sown at $50 \mathrm{~cm}$ and $70 \mathrm{~cm}$ between the rows achieved a deficit production, very significant compared to the control of the experience (Table 10).

Under the conditions of A.R.D.S. Secuieni, at the distances of $50 \mathrm{~cm}$ and $70 \mathrm{~cm}$ between the rows there was a decrease of the herb and seed production as compared to the control of the experience sowing at $25 \mathrm{~cm}$ between the rows and continuously row during the study period.

Table 3. The influence of interaction from the distance between rows and the distance between plants per row on the average height of the plant $(\mathrm{cm})$ at Dracocephalum moldavica L. (dragonhead) species, at A.R.D.S. Secuieni during $2016-2017$

\begin{tabular}{|c|c|c|c|c|c|}
\hline $\begin{array}{l}\text { Distance } \\
\text { between } \\
\text { rows (A) }\end{array}$ & $\begin{array}{l}\text { Distance between } \\
\text { plants per row (B) }\end{array}$ & $\begin{array}{l}\text { Height of the } \\
\text { plant }(\mathrm{cm})\end{array}$ & $\begin{array}{c}\% \\
\text { compared } \\
\text { to control. }\end{array}$ & Diff. & Significance \\
\hline \multirow{3}{*}{ a1-25 cm } & b1-continuous row & 83.83 & 100 & $\mathrm{Ct}$. & \\
\hline & $\mathrm{b} 2-15 \mathrm{~cm}$ & 79.19 & 94.47 & -4.64 & 000 \\
\hline & $\mathrm{b} 3-25 \mathrm{~cm}$ & 87.31 & 104.15 & 3.48 & $* *$ \\
\hline \multirow{3}{*}{$\mathrm{a} 2-50 \mathrm{~cm}$} & b1- continuous row & 81.39 & 97.08 & -2.44 & $\mathrm{oO}$ \\
\hline & $\mathrm{b} 2-15 \mathrm{~cm}$ & 84.61 & 100.93 & 0.78 & \\
\hline & $\mathrm{b} 3-25 \mathrm{~cm}$ & 85.99 & 102.57 & 2.16 & $*$ \\
\hline \multirow{3}{*}{$\mathrm{a} 3-70 \mathrm{~cm}$} & b1- continuous row & 84.98 & 101.37 & 1.15 & \\
\hline & $\mathrm{b} 2-15 \mathrm{~cm}$ & 85.63 & 102.15 & 1.80 & $*$ \\
\hline & $\mathrm{b} 3-25 \mathrm{~cm}$ & 84.94 & 101.32 & 1.11 & \\
\hline \multicolumn{6}{|c|}{ LSD $5 \%=1.59 \mathrm{~cm}$} \\
\hline
\end{tabular}


Table 4. The influence of interaction from the distance between rows and the distance between plants per row on the average number of branches per plant at Dracocephalum moldavica L. (dragonhead) species. at A.R.D.S.

Secuieni during $2016-2017$.

\begin{tabular}{|c|c|c|c|c|c|}
\hline $\begin{array}{c}\text { Distance } \\
\text { between rows } \\
\text { (A) }\end{array}$ & $\begin{array}{c}\text { Distance between } \\
\text { plants per row (B) }\end{array}$ & $\begin{array}{c}\text { Number of } \\
\text { branches } \\
\text { /plant }\end{array}$ & $\begin{array}{c}\text { \% } \\
\text { compared } \\
\text { to control }\end{array}$ & Diff. & Significance \\
\hline \multirow{3}{*}{ a1-25 cm } & b1- continuous row & 14.93 & 100 & $\mathrm{Ct}$. & \\
\cline { 2 - 6 } & $\mathrm{b} 2-15 \mathrm{~cm}$ & 14.67 & 98.21 & -0.27 & \\
\cline { 2 - 6 } & $\mathrm{b} 3-25 \mathrm{~cm}$ & 15.73 & 105.36 & 0.80 & \\
\hline \multirow{3}{*}{$\mathrm{a} 2-50 \mathrm{~cm}$} & $\mathrm{~b} 1-$ continuous row & 13.60 & 91.09 & -1.33 & \\
\cline { 2 - 6 } & $\mathrm{b} 2-15 \mathrm{~cm}$ & 14.67 & 98.25 & -0.26 & \\
\cline { 2 - 6 } & $\mathrm{b} 3-25 \mathrm{~cm}$ & 16.00 & 107.16 & 1.07 & \\
\hline \multirow{3}{*}{$\mathrm{a} 3-70 \mathrm{~cm}$} & $\mathrm{~b} 1-$ continuous row & 14.40 & 96.45 & -0.53 & \\
\cline { 2 - 6 } & $\mathrm{b} 2-15 \mathrm{~cm}$ & 17.20 & 115.20 & 2.27 & $* *$ \\
\cline { 2 - 6 } & $\mathrm{b} 3-25 \mathrm{~cm}$ & 15.73 & 105.35 & 0.8 & \\
\hline
\end{tabular}

Table 5. The influence of interaction from the distance between rows and the distance between plants per row on the average weight of the stems at Dracocephalum moldavica L. (dragonhead) species. at A.R.D.S. Secuieni during $2016-2017$.

\begin{tabular}{|c|c|c|c|c|c|}
\hline $\begin{array}{c}\text { Distance } \\
\text { between rows } \\
\text { (A) }\end{array}$ & $\begin{array}{l}\text { Distance between } \\
\text { plants per row (B) }\end{array}$ & $\begin{array}{l}\text { Weight of } \\
\text { the stems } \\
(\mathrm{g}) \\
\end{array}$ & $\begin{array}{c}\% \\
\text { compared } \\
\text { to control }\end{array}$ & Diff. & Significance \\
\hline \multirow{3}{*}{ a1-25 cm } & b1- continuous row & 43.79 & 100 & Ct. & \\
\hline & $\mathrm{b} 2-15 \mathrm{~cm}$ & 36.26 & 82.81 & -7.53 & \\
\hline & $\mathrm{b} 3-25 \mathrm{~cm}$ & 100.64 & 229.82 & 56.85 & $* *$ \\
\hline \multirow{3}{*}{$\mathrm{a} 2-50 \mathrm{~cm}$} & b1- continuous row & 39.35 & 89.86 & -4.44 & \\
\hline & $\mathrm{b} 2-15 \mathrm{~cm}$ & 78.86 & 180.08 & 35.07 & $*$ \\
\hline & $\mathrm{b} 3-25 \mathrm{~cm}$ & 110.75 & 252.91 & 66.96 & $* *$ \\
\hline \multirow{3}{*}{$\mathrm{a} 3-70 \mathrm{~cm}$} & b1- continuous row & 49.80 & 113.72 & 6.01 & \\
\hline & $\mathrm{b} 2-15 \mathrm{~cm}$ & 124.63 & 284.60 & 80.84 & $* * *$ \\
\hline & $\mathrm{b} 3-25 \mathrm{~cm}$ & 136.53 & 311.78 & 92.74 & $* * *$ \\
\hline & LSD $5 \%=29.17 \mathrm{~g}$ & $1 \%=45$ & \multicolumn{2}{|c|}{ LSD $0.1 \%=76.17 \mathrm{~g}$} & \\
\hline
\end{tabular}

Table 6. The influence of interaction from the distance between rows and the distance between plants per row on the average weight of the leaves at Dracocephalum moldavica L. (dragonhead) species. at A.R.D.S. Secuieni during $2016-2017$.

\begin{tabular}{|c|c|c|c|c|c|}
\hline $\begin{array}{c}\text { Distance } \\
\text { between rows } \\
(\mathbf{A})\end{array}$ & $\begin{array}{c}\text { Distance between } \\
\text { plants per row (B) }\end{array}$ & $\begin{array}{c}\text { Weight of } \\
\text { the leaves } \\
(\mathbf{g})\end{array}$ & $\begin{array}{c}\text { \% } \\
\text { compared } \\
\text { to control }\end{array}$ & Diff. & Significance \\
\hline \multirow{3}{*}{ a1-25 cm } & b1- continuous row & 54.17 & 100 & $\mathrm{Ct}$ & \\
\cline { 2 - 6 } & $\mathrm{b} 2-15 \mathrm{~cm}$ & 52.32 & 96.59 & -1.85 & \\
\cline { 2 - 6 } & $\mathrm{b} 3-25 \mathrm{~cm}$ & 134.75 & 248.78 & 80.59 & $* *$ \\
\hline \multirow{3}{*}{$\mathrm{a} 2-50 \mathrm{~cm}$} & $\mathrm{~b} 1-$ continuous row & 50.64 & 93.48 & -3.53 & \\
\cline { 2 - 6 } & $\mathrm{b} 2-15 \mathrm{~cm}$ & 97.14 & 179.32 & 42.97 & $*$ \\
\cline { 2 - 6 } & $\mathrm{b} 3-25 \mathrm{~cm}$ & 157.94 & 291.56 & 103.77 & $* *$ \\
\hline \multirow{3}{*}{ a3-70 cm } & $\mathrm{b} 1-$ continuous row & 65.99 & 121.82 & 11.82 & $* * *$ \\
\cline { 2 - 6 } & $\mathrm{b} 2-15 \mathrm{~cm}$ & 160.82 & 296.88 & 106.65 & $* * *$ \\
\cline { 2 - 6 } & $\mathrm{b} 3-25 \mathrm{~cm}$ & 173.05 & 319.45 & 118.88 & \\
\hline
\end{tabular}


Table 7. The influence of interaction from the distance between rows and the distance between plants per row on the average weight of the flowers at Dracocephalum moldavica L. (dragonhead) species. at A.R.D.S.

Secuieni during $2016-2017$.

\begin{tabular}{|c|c|c|c|c|c|}
\hline $\begin{array}{c}\text { Distance } \\
\text { between rows } \\
\text { (A) }\end{array}$ & $\begin{array}{l}\text { Distance between } \\
\text { plants per row (B) }\end{array}$ & $\begin{array}{l}\text { Weight of } \\
\text { the flowers } \\
(\mathrm{g})\end{array}$ & $\begin{array}{c}\% \\
\text { compared } \\
\text { to control }\end{array}$ & Diff. & Significance \\
\hline \multirow{3}{*}{ a1-25 cm } & b1- continuous row & 7.06 & 100 & Ct. & \\
\hline & $\mathrm{b} 2-15 \mathrm{~cm}$ & 8.36 & 118.46 & 1.30 & \\
\hline & $\mathrm{b} 3-25 \mathrm{~cm}$ & 14.31 & 202.74 & 7.25 & $* *$ \\
\hline \multirow{3}{*}{$\mathrm{a} 2-50 \mathrm{~cm}$} & b1- continuous row & 6.59 & 93.34 & -0.47 & \\
\hline & $\mathrm{b} 2-15 \mathrm{~cm}$ & 9.72 & 137.67 & 2.66 & \\
\hline & $\mathrm{b} 3-25 \mathrm{~cm}$ & 17.62 & 249.57 & 10.56 & $* *$ \\
\hline \multirow{3}{*}{$\mathrm{a} 3-70 \mathrm{~cm}$} & b1- continuous row & 7.33 & 103.82 & 0.27 & \\
\hline & $\mathrm{b} 2-15 \mathrm{~cm}$ & 18.79 & 266.15 & 11.73 & $* * *$ \\
\hline & $\mathrm{b} 3-25 \mathrm{~cm}$ & 28.69 & 406.37 & 21.63 & $* * *$ \\
\hline & LSD $5 \%=4.12 \mathrm{~g}$ & $\mathrm{D} 1 \%=6.41 \mathrm{~g}$ & LSD $0.1 \%$ & $.95 \mathrm{~g}$ & \\
\hline
\end{tabular}

Table 8. The influence of interaction from the distance between rows and the distance between plants per row on the average weight of the plant at Dracocephalum moldavica L. (dragonhead) species. at A.R.D.S. Secuieni during 2016 - 2017.

\begin{tabular}{|c|c|c|c|c|c|}
\hline $\begin{array}{c}\text { Distance } \\
\text { between rows } \\
\text { (A) }\end{array}$ & $\begin{array}{l}\text { Distance between } \\
\text { plants per row (B) }\end{array}$ & $\begin{array}{l}\text { Weight of } \\
\text { the plant }(\mathrm{g})\end{array}$ & $\begin{array}{c}\% \\
\text { compared } \\
\text { to control } \\
\end{array}$ & Diff. & Significance \\
\hline \multirow{3}{*}{ a1-25 cm } & b1- continuous row & 104.40 & 100 & $\mathrm{Ct}$. & \\
\hline & $\mathrm{b} 2-15 \mathrm{~cm}$ & 93.62 & 89.67 & -10.78 & \\
\hline & $\mathrm{b} 3-25 \mathrm{~cm}$ & 249.71 & 239.17 & 145.31 & $* *$ \\
\hline \multirow{3}{*}{$\mathrm{a} 2-50 \mathrm{~cm}$} & b1- continuous row & 96.59 & 92.52 & -7.81 & \\
\hline & $\mathrm{b} 2-15 \mathrm{~cm}$ & 187.39 & 179.49 & 82.99 & $*$ \\
\hline & $\mathrm{b} 3-25 \mathrm{~cm}$ & 286.32 & 274.25 & 181.92 & $* *$ \\
\hline \multirow{3}{*}{$\mathrm{a} 3-70 \mathrm{~cm}$} & b1- continuous row & 123.13 & 117.94 & 18.73 & \\
\hline & $\mathrm{b} 2-15 \mathrm{~cm}$ & 304.25 & 291.42 & 199.85 & $* * *$ \\
\hline & $\mathrm{b} 3-25 \mathrm{~cm}$ & 338.28 & 324.02 & 233.88 & $* * *$ \\
\hline & \multicolumn{5}{|c|}{$\mathrm{LSD} 5 \%=71.20 \mathrm{~g} \quad$ LSD $1 \%=109.8 \mathrm{~g}$} \\
\hline
\end{tabular}

Table 9. The influence of interaction from the distance between rows and the distance between plants per row on the average fresh herbs $(\mathrm{kg} / \mathrm{ha})$ at Dracocephalum moldavica L. (dragonhead) species. at A.R.D.S. Secuieni during $2016-2017$.

\begin{tabular}{|c|c|c|c|c|c|}
\hline $\begin{array}{c}\text { Distance } \\
\text { between rows } \\
\text { (A) }\end{array}$ & $\begin{array}{l}\text { Distance between } \\
\text { plants per row (B) }\end{array}$ & $\begin{array}{l}\text { Production } \\
\text { of fresh herb } \\
(\mathrm{kg} / \mathrm{ha})\end{array}$ & $\begin{array}{c}\% \\
\text { compared } \\
\text { to control }\end{array}$ & Diff. & Significance \\
\hline \multirow{3}{*}{ a1-25 cm } & b1- continuous row & 57866 & 100 & Ct. & \\
\hline & $\mathrm{b} 2-15 \mathrm{~cm}$ & 57186 & 98.82 & -680 & \\
\hline & $\mathrm{b} 3-25 \mathrm{~cm}$ & 41880 & 72.37 & -15986 & OO \\
\hline \multirow{3}{*}{$\mathrm{a} 2-50 \mathrm{~cm}$} & b1- continuous row & 38683 & 66.84 & -19183 & OoO \\
\hline & $\mathrm{b} 2-15 \mathrm{~cm}$ & 30383 & 52.50 & -27483 & OOO \\
\hline & $\mathrm{b} 3-25 \mathrm{~cm}$ & 29776 & 51.45 & -28090 & OOO \\
\hline \multirow{3}{*}{$\mathrm{a} 3-70 \mathrm{~cm}$} & b1- continuous row & 33566 & 58.01 & -24300 & OOO \\
\hline & $\mathrm{b} 2-15 \mathrm{~cm}$ & 34866 & 60.25 & -23000 & OOO \\
\hline & $\mathrm{b} 3-25 \mathrm{~cm}$ & 29250 & 50.54 & -28616 & 000 \\
\hline \multicolumn{6}{|c|}{ LSD $5 \%=7811 \mathrm{~kg} / \mathrm{ha}$} \\
\hline
\end{tabular}


Table 10. The influence of interaction from the distance between rows and the distance between plants per row on the average seed production ( $\mathrm{kg} / \mathrm{ha})$ at Dracocephalum moldavica L. (dragonhead) species. at A.R.D.S.

Secuieni during $2016-2017$.

\begin{tabular}{|c|c|c|c|c|c|}
\hline $\begin{array}{l}\text { Distance between } \\
\text { rows (A) }\end{array}$ & $\begin{array}{l}\text { Distance between } \\
\text { plants per row (B) }\end{array}$ & $\begin{array}{l}\text { Production } \\
\text { (kg/ha) }\end{array}$ & $\begin{array}{c}\% \\
\text { compared } \\
\text { to control }\end{array}$ & Diff. & Significance \\
\hline \multirow{3}{*}{ a1-25 cm } & b1- continuous row & 1033 & 100 & Ct. & \\
\hline & $\mathrm{b} 2-15 \mathrm{~cm}$ & 1154 & 111.71 & 121 & * \\
\hline & $\mathrm{b} 3-25 \mathrm{~cm}$ & 1063 & 102.90 & 30 & \\
\hline \multirow{3}{*}{$\mathrm{a} 2-50 \mathrm{~cm}$} & b1- continuous row & 517 & 50.04 & -516 & 000 \\
\hline & $\mathrm{b} 2-15 \mathrm{~cm}$ & 570 & 55.17 & -463 & 000 \\
\hline & $\mathrm{b} 3-25 \mathrm{~cm}$ & 723 & 69.99 & -310 & 000 \\
\hline \multirow{3}{*}{$\mathrm{a} 3-70 \mathrm{~cm}$} & b1- continuous row & 670 & 64.85 & -363 & 000 \\
\hline & $\mathrm{b} 2-15 \mathrm{~cm}$ & 589 & 57.01 & -444 & 000 \\
\hline & $\mathrm{b} 3-25 \mathrm{~cm}$ & 619 & 59.92 & -414 & 000 \\
\hline
\end{tabular}

\section{CONCLUSIONS}

In Dracocephalum moldavica L. the average weight of the stem showed distinct positive differences. compared to the a1xb1 $(43.79 \mathrm{~g})$. at the interactions between a1xb3 $(56.85 \mathrm{~g}-$ sown at $25 \mathrm{~cm}$ between rows and $25 \mathrm{~cm}$ between plants per row) and a $2 \times b 3$ ( $66.96 \mathrm{~g}$ - sown at $50 \mathrm{~cm}$ between rows and $25 \mathrm{~cm}$ between plants per row).

At Dracocephalum moldavica L. the average plant weight was revealed by distinct positive differences compared to the a1 $\mathrm{xb} 1$ (104.4 $\mathrm{g}$ sown at $25 \mathrm{~cm}$ between row in a continuous row) on the interactions between a1xb3 (145.31 g) and a2xb3 (181.92 g).

Average seed yield per hectare showed significant positive differences in a1 xb2 interaction ( $25 \mathrm{~cm}$ between rows and $15 \mathrm{~cm}$ between plants $-124 \mathrm{~kg} / \mathrm{ha})$ compared to the control a1 xb1 (1033 kg/ha sown at $25 \mathrm{~cm}$ between rows in a continuous row).

\section{REFERENCES}

[1] El-Baky. H.H.. El-Baroty. G.S.. Chemical and biological evaluation of the essential oil of Egyptian moldavian balm. Global journal of biotechnology biochemistry. 2007. p. 74-80.

[2] Galambosi. B.. Holm. Y.. The effect of nitrogen fertilization on the herb yield of dragonhead. Journal of agricultural science in Fanland. vol. 61. 1989. p. 387-394.

[3] Hassani. A.. Effect of water deficit stress on growth. yield and essential oil content of (Dracocephalum moldavica L.). Iranian journal of medicinal and aromatic plants research. 2006. p. 256-261.

[4] Mozaffarian. V.. A dictionary of iranian plant. Names.farhang moaser. Tehran. Iran. 1996. p. 542.

[5] Omidbaigi. R.. Production and processing of medicinal plants. Astan quds razavi publications. Behnashr. Mashhad. vol. 2. 2005. p. 438.

[6] Abedi. R.. Golparvar. A.R. Hadipanah. A.. Identification of the essential oils composition from four ecotypes of Mentha longifolia (L.) Huds. Growing wild in Isfahan province. Iran. Journal of bio science and biotechnology. 2015. p. 117-121. 